\title{
Gliotoxin Inhibits Neointimal Hyperplasia after Vascular Injury in Rats
}

\author{
Mayte Pozo María Concepción Izquierdo Rosario de Nicolás Jesús Egido \\ Alberto Ortiz Jesús González-Cabrero ${ }^{1}$ \\ Fundación Jiménez Díaz y Universidad Autónoma de Madrid, Madrid, España
}

\section{Key Words}

Carotid artery - Cytoskeleton - Migration of cells . Neointimal formation $\cdot$ Proliferation of cells $\cdot$ Vascular smooth muscle cells

\begin{abstract}
Neointima formation participates in the pathophysiology of atherosclerosis and restenosis. Proliferation and migration of vascular smooth muscle cells (VSMC) are initial responses to vascular injury. The aim of the present study was to assess the effect of gliotoxin, an inhibitor of nuclear factor (NF)- $\mathrm{B}$, on migration and proliferation of cultured rat VSMC and neointimal formation in injured rat vessels. In cultured VSMC, gliotoxin inhibited the nuclear translocation of the p 65 subunit of NF- $\kappa B$ in response to inflammatory stimuli. In addition, gliotoxin inhibited VSMC migration and proliferation in response to platelet-derived growth factor-BB. This was associated with a rapid rearrangement of the F-actin and vimentin cytoskeleton. Furthermore, gliotoxin inhibited endothelial cell nuclear translocation of p65, cell surface expression of adhesion molecules such as VCAM-1, ICAM-1 and E-selectin, and monocytic cell adhesion to a cytokine-activated endothelial monolayer. In the rat carotid artery balloon catheter injury model, the systemic administration of gliotoxin for 10 days decreased neointimal hyperplasia and luminal stenosis by up to $90 \%$ and decreased the expression of proliferating cell nuclear antigen in the vessel wall by up to $70 \%$, depending on the dose. These observations suggest
\end{abstract}

that gliotoxin favorably regulates the response to vascular injury through actions on VSMC. However, further studies evaluating the therapeutic benefit of gliotoxin in restenosis after balloon angioplasty are required.

Copyright $\odot 2008$ S. Karger AG, Basel

\section{Introduction}

Neointimal hyperplasia has been identified as one of the mechanisms of arterial restenosis after balloon angioplasty in humans. The high frequency of restenosis (30-50\% of patients) limited the long-term success of percutaneous transluminal coronary techniques [1-3]. The use of drug-eluting stents has greatly reduced the incidence of restenosis [4-7]. However, recent reports suggest that sirolimus- or paclitaxel-eluting stents are associated with an increased risk of late stent thrombosis, a potentially fatal complication, when compared with bare-metal stents [8-13]. Thus, the search for alternative agents would be desirable. Gliotoxin belongs to the epipolythiodioxopiperazine class of biologically active secondary fungal metabolites [14]. It is characterized by the presence of a quinoid moiety and a disulfide bridge across the piperazine ring that is essential for its activity. Gliotoxin exhibits profound immunosuppressive effects both in vitro and in vivo, inhibiting activation and proliferation of

1 Deceased.

\section{KARGER}

Fax +41613061234

E-Mail karger@karger.ch

www.karger.com (c) 2008 S. Karger AG, Basel

1018-1172/09/0464-0278\$26.00/0

Accessible online at:

www.karger.com/jvr
Dr. Alberto Ortiz

Unidad de Diálisis, Fundación Jiménez Díaz

Avenida Reyes Católicos, 2

ES-28040 Madrid (Spain)

Tel. +34 91550 4821, Fax +34 1549 4764, E-Mail aortiz@fjd.es 
$\mathrm{B}$ and $\mathrm{T}$ lymphocytes [15-18]. In addition, gliotoxin inhibits the activation of the transcription factor nuclear factor (NF)- $\kappa \mathrm{B}[17,19,20]$ and has proven safe and effective in controlling inflammation in animal models [21].

Arterial wall injury leads to intimal thickening and luminal stenosis, with vascular smooth muscle cells (VSMC) as key players [22-24]. Endothelial denudation of the rat carotid artery by angioplasty has provided a rapid, highly reproducible and widely used model to study cellular and molecular events in VSMC leading to neointimal formation and restenosis [3, 25-27].

The main purpose of the current study was to evaluate the effect of gliotoxin on the inhibition of neointimal hyperplasia in a rat model of vascular injury induced by balloon angioplasty and to explore the possible contribution of direct actions on VSMC, investigating the potential role of gliotoxin therapy in the prevention of restenosis.

\section{Materials and Methods}

\section{Cell Cultures}

Thoracic aortas from Sprague-Dawley rats were removed and stripped of endothelium and adventitia. The vessels were cut into small segments. VSMC were isolated by collagenase type II (Sigma) enzymatic digestion and the explant method [28]. Cell cultures were maintained at $37^{\circ} \mathrm{C}$ in $5 \% \mathrm{CO}_{2}$ in Dulbecco's modified minimal essential media (DMEM; Gibco), supplemented with $10 \%$ fetal calf serum (FCS), glutamine, penicillin, streptomycin and fungizone. Cells from passages 3-8 were studied. Purity was $98 \%$, as assessed by positive immunostaining with anti-smooth muscle $\alpha$-actin monoclonal antibody (Sigma).

Human umbilical vein endothelial cells were cultured as described elsewhere [29]. Briefly, umbilical veins were cannulated and perfused with M199 culture medium to remove blood, and then incubated with $0.1 \%$ type $\mathrm{P}$ collagenase (Roche Diagnostics) for $20 \mathrm{~min}$ at $37^{\circ} \mathrm{C}$. After removal of collagenase, cells were harvested and cultured in M199 medium (BioWittaker) with 20\% heat-inactivated FCS and antibiotics. Confluent cells between the first and fourth passage were studied. Cells were maintained in M199 medium with $10 \%$ FCS, $50 \mu \mathrm{g} / \mathrm{ml}$ endothelial cell growth supplement, $100 \mu \mathrm{g} / \mathrm{ml}$ heparin (Sigma) and antibiotics. The purity of endothelial cell cultures was characterized by the typical cobblestone morphology and $>98 \%$ positive staining for von Willebrand's factor.

Human monocytic THP-1 cells were obtained from the American Type Culture Collection and maintained in RPMI 1640 medium (Gibco) with 10\% FCS and antibiotics.

\section{Cell Migration Assays}

Rat VSMC chemotaxis was studied using Transwell ${ }^{\circledR}$ inserts with polycarbonate membranes ( $8-\mu \mathrm{m}$ pore size; Costar). Cells were suspended at $5 \times 10^{5} / \mathrm{ml}$ in DMEM containing $0.5 \%$ BSA (DMEM-BSA), added to the upper chamber in a final volume of $100 \mu \mathrm{l}$ and treated with gliotoxin (Sigma). Chemotaxis chambers were assembled by adding $50 \mathrm{ng} / \mathrm{ml}$ platelet-derived growth fac- tor (PDGF)-BB (PeproTech) in DMEM-BSA to the lower compartments in a final volume of $600 \mu \mathrm{l}$. After $18 \mathrm{~h}$ of incubation at $37^{\circ} \mathrm{C}$, the cells on the upper surface were mechanically removed, and cells remaining on the underside of the filters were fixed in $2 \%$ paraformaldehyde and stained with $0.5 \%$ crystal violet. The color was eluted with $10 \%$ acetic acid, and measured at $600 \mathrm{~nm}$ in a spectrophotometer. Specific chemotaxis was expressed as the percentage of VSMC that migrated in response to PDGF-BB without gliotoxin. All data points were assessed in duplicate for each condition.

\section{Immunofluorescence}

Cytoskeletal protein organization, proliferating cell nuclear antigen (PCNA) expression and nuclear translocation of NF- $\mathrm{B}$ p65 were assessed by immunofluorescence in subconfluent cells cultured on 8-well glass chamber slides (Lab-Tek; Nalge Nunc).

To assess cytoskeletal proteins, cells were incubated with 100 $\mathrm{ng} / \mathrm{ml}$ gliotoxin for $1 \mathrm{~h}$, fixed in $2 \%$ paraformaldehyde for $20 \mathrm{~min}$ and permeabilized with $0.1 \%$ Triton X-100 for $10 \mathrm{~min}$. F-actin was stained with $800 \mu \mathrm{M}$ FITC-labeled phalloidin (Sigma) for $30 \mathrm{~min}$ at room temperature. Vimentin and $\beta$-tubulin were stained with specific monoclonal antibodies on ice for $45 \mathrm{~min}$ (Sigma), followed by an FITC anti-mouse IgG (Sigma). After rinsing with PBS, samples were mounted with $90 \%$ buffered glycerin. Immunofluorescence was determined using a Nikon Eclipse E400 microscope and photographed with a Nikon Coolpix 990 digital camera.

To assess PCNA expression, cells were growth arrested in serum-free medium for $48 \mathrm{~h}$ before preincubation with $100 \mathrm{ng} / \mathrm{ml}$ gliotoxin for $90 \mathrm{~min}$ and subsequent stimulation with DMEM/ $10 \%$ FCS or $10 \mathrm{ng} / \mathrm{ml}$ PDGF-BB for $24 \mathrm{~h}$. Cells were fixed and permeabilized with methanol/acetone $(1: 1)$ at $4{ }^{\circ} \mathrm{C}$ for $15 \mathrm{~min}$. Immunostaining was performed with anti-PCNA antibody clone PC10 (Sigma) at $4^{\circ} \mathrm{C}$ for $24 \mathrm{~h}$; then an FITC goat anti-mouse IgG was added for $45 \mathrm{~min}$ at $4^{\circ} \mathrm{C}$.

To assess nuclear translocation of p65, cells preincubated with $100 \mathrm{ng} / \mathrm{ml}$ gliotoxin for $1 \mathrm{~h}$ were treated with $30 \mathrm{ng} / \mathrm{ml} \mathrm{IL-1 \beta}$ (PeproTech) for $2.5 \mathrm{~h}$, and then fixed and permeabilized with paraformaldehyde and Triton X-100. Primary antibody was rabbit polyclonal anti-p65 (Santa Cruz Biotechnology) at $37^{\circ} \mathrm{C}$ for $1 \mathrm{~h}$. Then FITC-goat anti-rabbit IgG (Sigma) was added for $45 \mathrm{~min}$ at room temperature.

Monocytic Cell Adhesion to Endothelial Cells

For cell adhesion studies, $10^{4}$ endothelial cells were seeded in gelatin-coated 96-well plates (Costar), grown to confluence and pretreated with gliotoxin for $1 \mathrm{~h}$ in M199 containing 0.5\% BSA (M199-BSA). Subsequently, cells were stimulated with $50 \mathrm{ng} / \mathrm{ml}$ IL- $1 \beta$ (Immugenex) at $37^{\circ} \mathrm{C}$ for 4 or $24 \mathrm{~h}$. After washing, $100 \mu \mathrm{l}$ of $2 \times 10^{6} \mathrm{THP}-1$ cells $/ \mathrm{ml}$ in RPMI-BSA, labeled with $2^{\prime}, 7^{\prime}$-bis $(2-$ carboxyethyl)-5(6)-carboxyfluorescein acetoxymethyl ester (Molecular Probes), were added to each well. THP-1 cells were allowed to adhere to the endothelial monolayer for $1 \mathrm{~h}$ at $37^{\circ} \mathrm{C}$, and nonadherent cells were washed off with six rounds of fresh medium. The residual adherent cells were quantified in a spectrofluorometer (Luminescence Spectrometer LS50B; Perkin Elmer). All assays were performed in triplicate, and the percentage of adhesion was referred to IL-1 $\beta$-activated endothelial cells in the absence of inhibitors, after subtraction of adherence to untreated cells. 


\section{Flow Cytometry}

Cell surface expression of VCAM-1, ICAM-1 and E-selectin was analyzed by flow cytometry. Confluent endothelial cells were activated with $50 \mathrm{ng} / \mathrm{ml} \mathrm{IL-1 \beta}$ for 4 or $24 \mathrm{~h}$. Cells were detached with Versene (EDTA) solution (BioWittaker) and stained with monoclonal antibodies to VCAM-1/CD106 (clone 1.G11B1), ICAM-1/CD54 (clone P2A4) and E-selectin/CD62E (clone P2H3; Endogen) for $30 \mathrm{~min}$ at $4^{\circ} \mathrm{C}$. The secondary antibody was FITC goat anti-mouse IgG (Sigma). Negative controls were prepared by omitting the first specific antibody. Cells were fixed in $1 \%$ paraformaldehyde in PBS and fluorescence quantified in an EPICS XL-MCL flow cytometer.

\section{Vascular Injury in Rat Carotid Artery}

Male Sprague-Dawley rats (450-500 g) were anesthetized by intramuscular administration of ketamine (Ketolar; Parke Davis) and xylazine (Rompun; Bayer). The left common carotid artery was denuded of endothelium with a 2 -french Fogarty balloon angioplasty catheter (Baxter), leaving the uninjured right side as a control. The balloon was introduced through an incision in the external carotid artery down to the aortic arch, inflated with saline, retracted along the full length of the common carotid artery and then deflated. This procedure was repeated three times, with the catheter turned $90^{\circ}$ each time while being retracted. After removal of the catheter, the left external carotid artery was permanently ligated. Eight rats were treated with 200 or $400 \mu \mathrm{g}$ gliotoxin/kg body weight/day i.p. $4 \mathrm{~h}$ after injury and daily for 10 days. The dose was chosen based on previous laboratory experience [21]. Gliotoxin was well tolerated, and no adverse effects were noted in terms of body weight or general well-being. All animal studies were performed according to protocols approved by the Animal Care and Use Committee of our Institution, following international regulations.

Tissue Processing and Quantitative Histomorphometric Analysis

Ten days after injury, the common carotid arteries were cleared of blood with saline, excised, immediately embedded in Tissue-Tek OCT medium (Sakura) and frozen. Using a cryostat (Leica; Leitz), arteries were cut in transverse rings (7- $\mu \mathrm{m}$ sections) taken from the center portion of the vessels, spaced at 0.5 $\mathrm{mm}$ intervals and stained using hematoxylin and eosin. Neointimal thickness was determined by subtracting the area defined by the luminal surface from the area defined by the internal elastic lamina, and the medial thickness was determined by the area of the internal elastic lamina subtracted from the external elastic lamina, using a computer-based image analysis program (Cellular Analysis System; Becton Dickinson) and a Nikon scope. Morphometry was performed in at least five individual sections of each arterial segment, and measurements were averaged for statistical analysis to determine the intima/media ratio and luminal stenosis.

\section{Immunohistochemistry}

Proliferative activity was evaluated in cryostat sections of carotid arteries. Slides were pretreated with cold acetone for $10 \mathrm{~min}$ and methanol with $0.3 \% \mathrm{H}_{2} \mathrm{O}_{2}$ for 30 min to block endogenous peroxidase. Samples were incubated with anti-PCNA clone PC10 (1:50) for $24 \mathrm{~h}$ at $4^{\circ} \mathrm{C}$, followed by a horseradish peroxidase-conjugated IgG (Amersham Biosciences) diluted 1:200 for $1 \mathrm{~h}$ at $4^{\circ} \mathrm{C}$.
Color was developed by a diaminobenzidine chromogen system (Dako). Samples were slightly counterstained with hematoxylin. Cells were considered positive for PCNA expression only in the presence of an intense brown staining of the nucleus.

Statistical Analysis

Results are presented as means \pm SD. Statistical comparisons were analyzed by nonparametric Mann-Whitney test or ANOVA, and values of $\mathrm{p}<0.05$ were considered significant.

\section{Results}

\section{Gliotoxin Inhibits PDGF-BB-Induced Migration of VSMC}

We first addressed the influence of gliotoxin on the migration of rat VSMC in response to PDGF-BB, one of the most powerful chemoattractants for VSMC [30-32]. Gliotoxin abolished the chemotactic response of VSMCs to PDGF-BB in a time- and dose-dependent manner (fig. 1). Treatment of VSMC with $100 \mathrm{ng} / \mathrm{ml}$ gliotoxin for $1 \mathrm{~h}$ inhibited $31 \%$ of migration referred to the positive control (fig. 1a). Inhibition increased to $45 \%$ with $200 \mathrm{ng} /$ $\mathrm{ml}$ gliotoxin (data not shown). An inhibition very close to basal levels was found after a 3-hour incubation with 200 $\mathrm{ng} / \mathrm{ml}$ gliotoxin (fig. 1b). Gliotoxin was not cytotoxic for VSMC as assessed by the MTT (3-[4,5-dimethylthiazol2-yl]-2,5 diphenyl tetrazolium bromide) reduction colorimetric assay [33].

\section{Gliotoxin Rearranges the Actin and Vimentin \\ Cytoskeleton of VSMC}

We next studied possible mechanisms whereby gliotoxin abolished the migratory response of vascular cells. Cellular locomotion is mediated by coordinated changes in the assembly and disassembly of F-actin fibers [34, 35]. VSMC growing under control conditions showed normal appearance of the F-actin cytoskeleton containing numerous microfilaments organized in stress fibers, which traverse the length of the cells (fig. 2a). Incubation with $100 \mathrm{ng} / \mathrm{ml}$ gliotoxin for $1 \mathrm{~h}$ resulted in a complete disorganization of the F-actin cytoskeleton (fig. 2b). Vimentin formed a fine fibrillar network, filling almost the whole cytoplasm, and extended to the cell periphery in untreated cells (fig. 2c). After incubation with $100 \mathrm{ng} / \mathrm{ml}$ gliotoxin for $30 \mathrm{~min}$, vimentin filaments redistributed and aggregated into dense structures at the perinuclear area (fig. 2d). By contrast, the basal distribution pattern of $\beta$ tubulin (fig. 2e), displaying a radial architecture of microtubules connected to the perinuclear region and reaching the plasma membrane, was barely modified by 


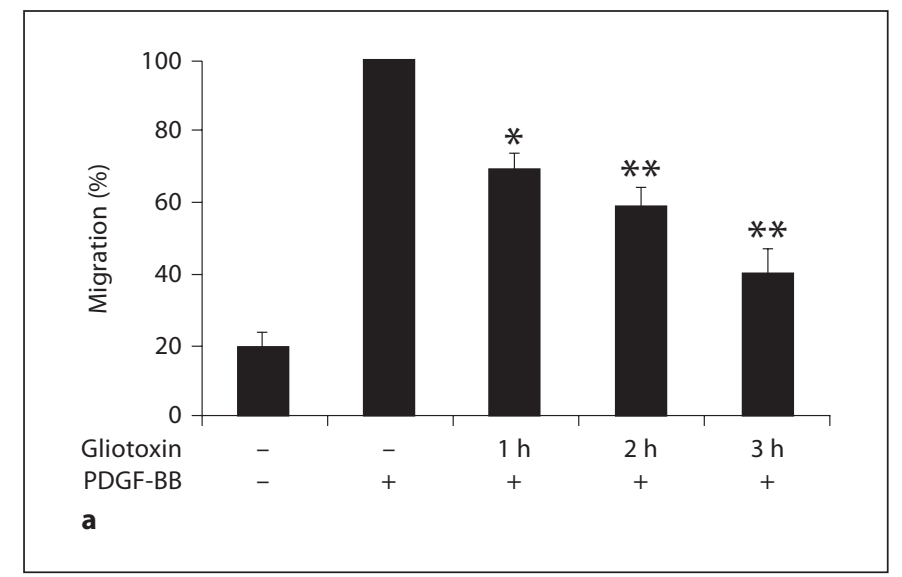

Fig. 1. Gliotoxin inhibits VSMC migration in a time (a)- and dosedependent (b) manner. Cells were seeded on the upper chamber of Transwell inserts, and chemotaxis was induced by $50 \mathrm{ng} / \mathrm{ml}$ PDGF-BB added to the lower compartment for $18 \mathrm{~h}$. a VSMC were pretreated with $100 \mathrm{ng} / \mathrm{ml}$ gliotoxin for $1-3 \mathrm{~h}$ before the addition of PDGF-BB. Data are means \pm SD from three independent experiments performed in duplicate. ${ }^{*} \mathrm{p}<0.005$; ${ }^{*} \mathrm{p}<0.0001$, vs.

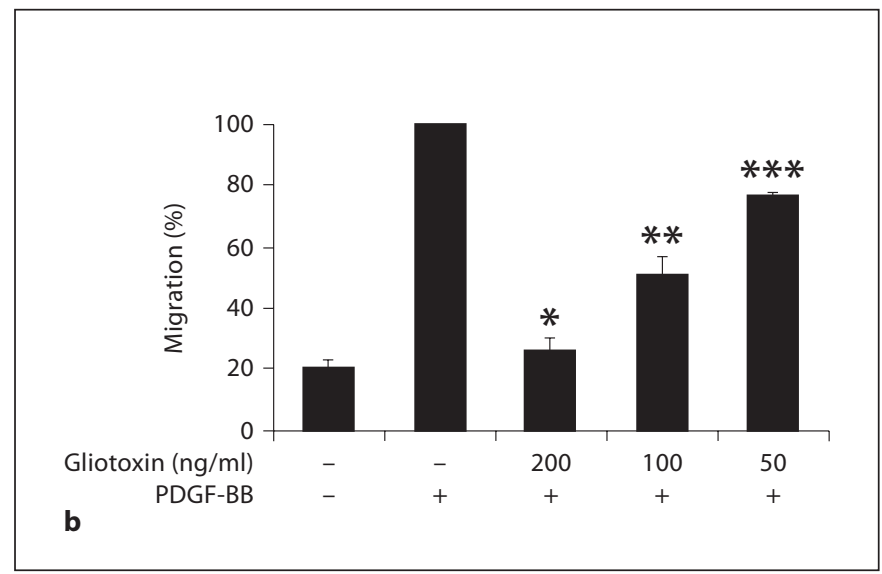

cell migration in response to PDGF-BB without gliotoxin. b VSMC were pretreated with serial concentrations of gliotoxin for $3 \mathrm{~h}$ before the addition of PDGF-BB. Results are means \pm $\mathrm{SD}$ from four independent experiments performed in duplicate. ${ }^{*} \mathrm{p}<0.0001 ;{ }^{* *} \mathrm{p}<0.0009$; ${ }^{* * *} \mathrm{p}<0.05$, vs. cell migration in response to PDGF-BB without gliotoxin.
Fig. 2. Gliotoxin rearranges the cytoskeletal architecture of actin and vimentin in VSMC. The distribution of cytoskeletal proteins was studied by immunofluorescence. Cells were examined under control conditions $(\mathbf{a}, \mathbf{c}, \mathbf{e})$ or after treatment with $100 \mathrm{ng} / \mathrm{ml}$ gliotoxin (b, d, f) for $1 \mathrm{~h}$. VSMC were stained with FITC-phalloidin for F-actin (a, b) and with antibodies against vimentin $(\mathbf{c}, \mathbf{d})$ and $\beta$-tubulin $(\mathbf{e}, \mathbf{f})$. Fluorescent micrographs are representative of at least three independent experiments. Original magnification, $\times 400$.

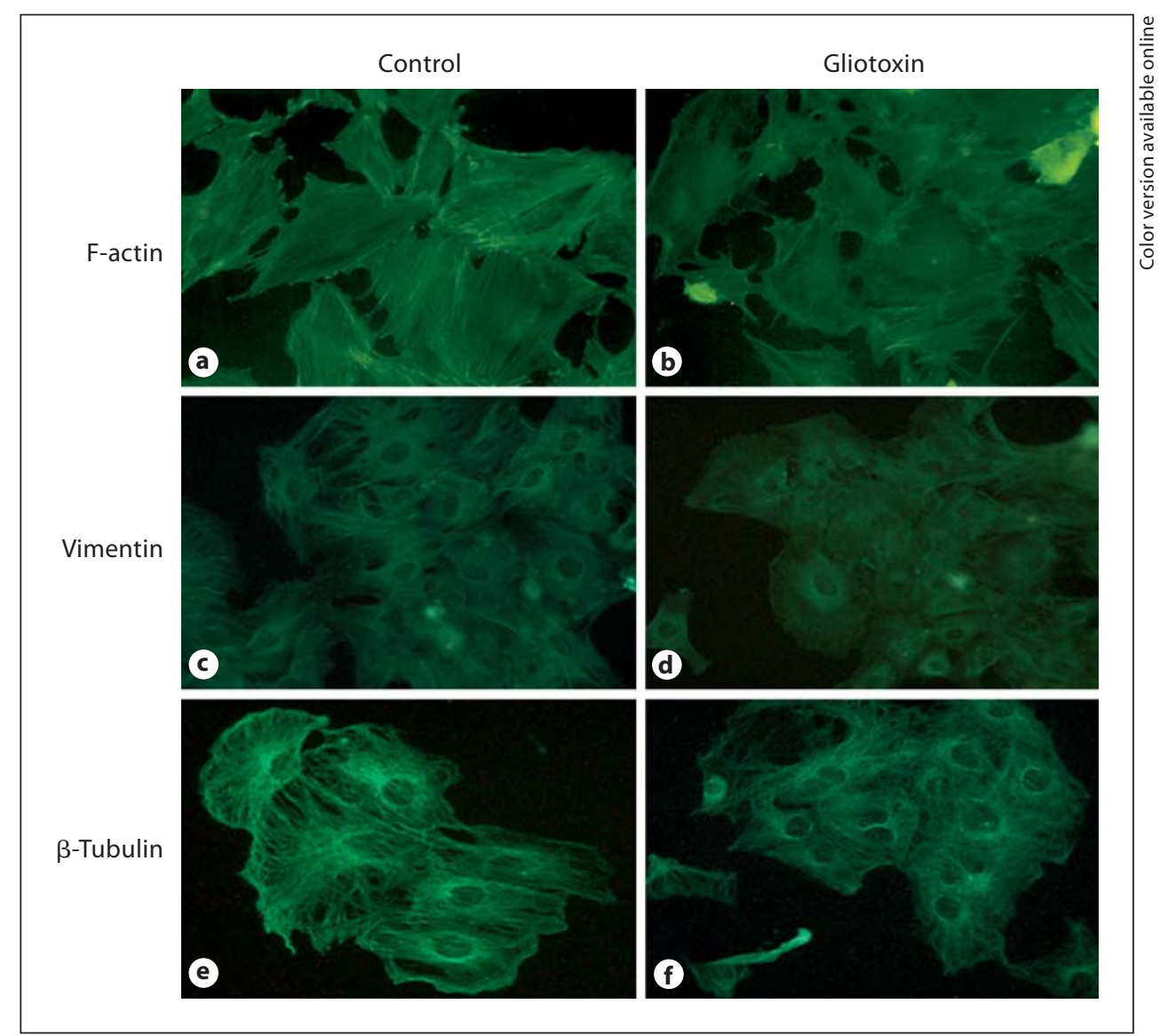




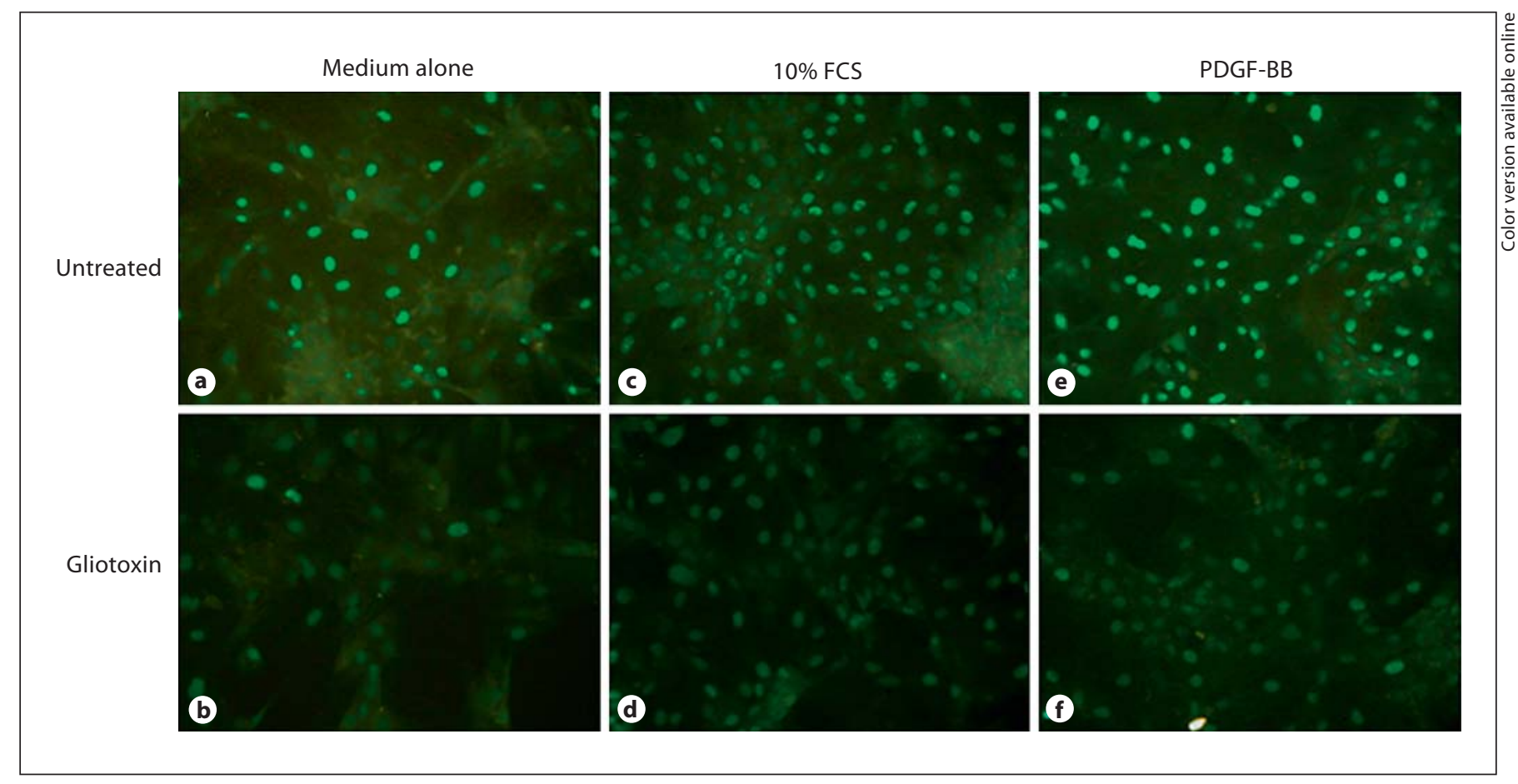

Fig. 3. Gliotoxin inhibits the expression of PCNA in VSMC. Quiescent cells were untreated (a, c, e) or preincubated with $100 \mathrm{ng} /$ $\mathrm{ml}$ gliotoxin for $90 \mathrm{~min}(\mathbf{b}, \mathbf{d}, \mathbf{f})$, and then cultured in medium alone (a, b), stimulated with $10 \%$ FCS (c, d) or with $10 \mathrm{ng} / \mathrm{ml}$ PDGF-BB (e, f) for $24 \mathrm{~h}$. Representative images of three independent experiments are shown. Original magnification, $\times 200$. g PCNA was quantified by counting positive nuclei (expressed as the percentage referred to total nuclei). Data are means $\pm \mathrm{SD}$ from 6 independent experiments ( 10 fields for each condition per experiment). ${ }^{*} \mathrm{p}<0.023 ;{ }^{* *} \mathrm{p}<0.0001$, untreated cultures $(\boldsymbol{\square})$ vs. gliotoxin-treated groups ( $\square)$.

incubation with gliotoxin (fig. 2f). Cell shape remained unchanged after treatments.

\section{Gliotoxin Inhibits the Expression of PCNA in VSMC}

Together with migration, proliferation also plays a key role in restenosis $[36,37]$. PCNA is a marker of cells that are actively proliferating. We studied the effect of gliotoxin on VSMC proliferation induced by two potent mitogens for these cells, serum and PDGF-BB. Immunocytochemical analysis of quiescent cells showed a small number of PCNA-positive nuclei (fig. 3a), the staining being virtually absent after gliotoxin treatment (fig. 3b). Strong fluorescence was observed in most nuclei after in-

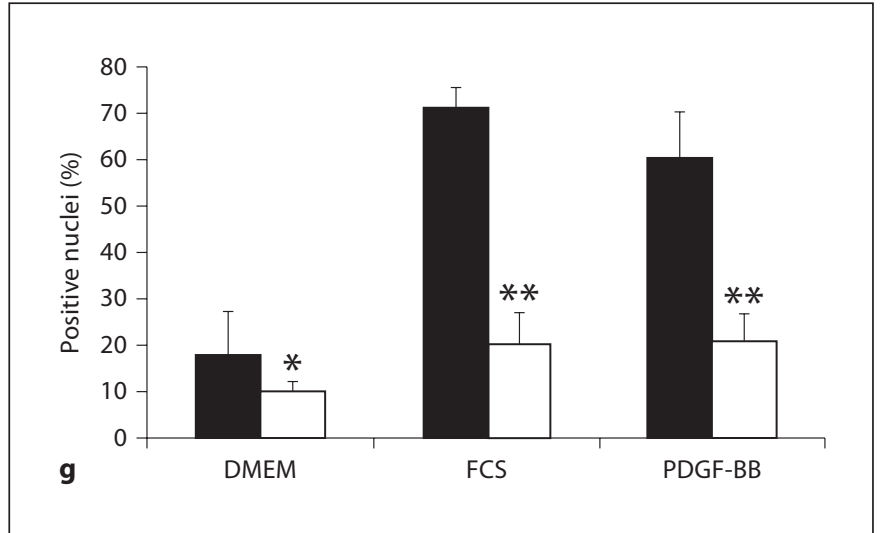

cubation for $24 \mathrm{~h}$ with both serum (fig. 3c) or PDGF-BB (fig. 3e). Pretreatment with gliotoxin decreased the number of PCNA-positive cells by $72 \%$ in the case of serum (fig. 3d) and by $66 \%$ for PDGF-BB (fig. 3f, quantified in fig. 3g).

Gliotoxin Inhibits the Nuclear Translocation of the $N F-\kappa B$ p 65 Subunit in VSMC

Nuclear translocation of p65 is necessary for its transcription factor activity. Inflammatory cy tokines, such as IL-1 $\beta$, promote NF- $\kappa \mathrm{B}$ activation [38-40]. In untreated VSMC, p65 immunoreactivity is present in cytoplasm but absent from nuclei (fig. 4a). IL-1 $\beta$ reduced cytoplas- 


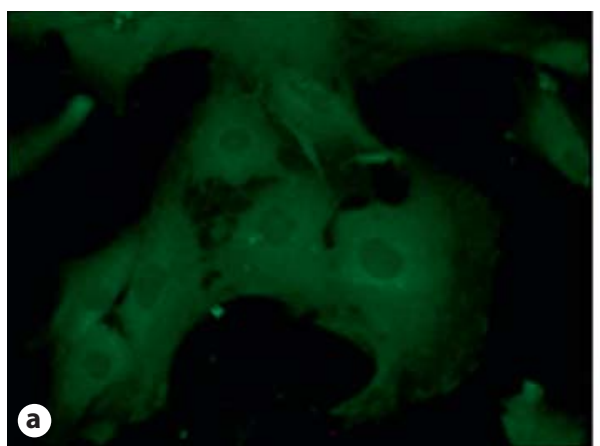

Untreated

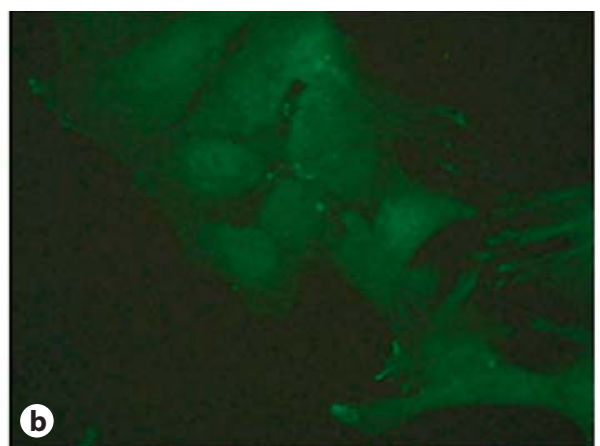

IL-1 $\beta$

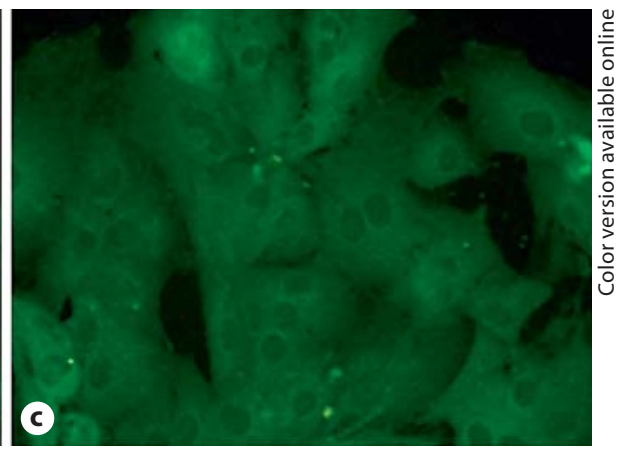

$\mathrm{IL}-1 \beta+$ gliotoxin
Fig. 4. Gliotoxin prevents the nuclear translocation of NF-кB p65 in VSMC. Fluorescent micrographs show the cytosolic localization of p65 in untreated control cells (a) and the nuclear translocation following stimulation with $30 \mathrm{ng} / \mathrm{ml} \mathrm{IL-1 \beta}$ for $2.5 \mathrm{~h}$ (b) which was prevented by pretreatment with $100 \mathrm{ng} / \mathrm{ml}$ gliotoxin (c). Representative images of three independent experiments are shown. Original magnification, $\times 400$.

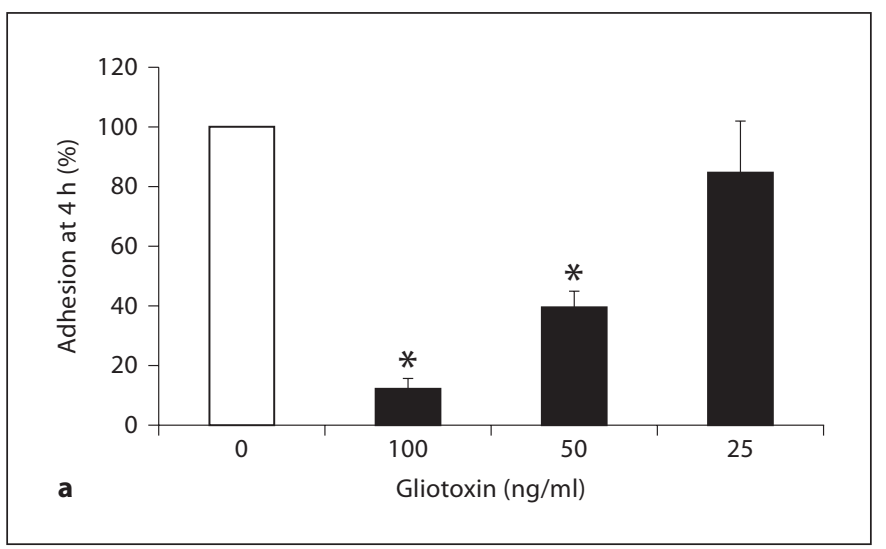

Fig. 5. Gliotoxin inhibits the adhesion of THP-1 monocytic cells to IL-1 $\beta$-activated endothelial cells. Endothelial cells treated with different concentrations of gliotoxin for $1 \mathrm{~h}$ were activated with $50 \mathrm{ng} / \mathrm{ml} \mathrm{IL-1 \beta}$ for 4 (a) or $24 \mathrm{~h}$ (b). Adhesion of THP-1 cells was

mic staining and resulted in new nuclear staining, demonstrating translocation of the activated NF- $\kappa \mathrm{B}$ protein from the cytoplasm to the nucleus (fig. 4b). Pretreatment of cells with $100 \mathrm{ng} / \mathrm{ml}$ gliotoxin prevented the nuclear translocation of p65 induced by IL-1 $\beta$ (fig. 4c), suggesting that gliotoxin inhibited the activation of this nuclear factor in rat VSMC.

\section{Gliotoxin Inhibits Monocytic Cell Adhesion to} Activated Endothelial Cells

Adhesion to an activated endothelium is the first step in leukocyte extravasation. Pretreatment of endothelial cells with gliotoxin for $1 \mathrm{~h}$ dose-dependently reduced

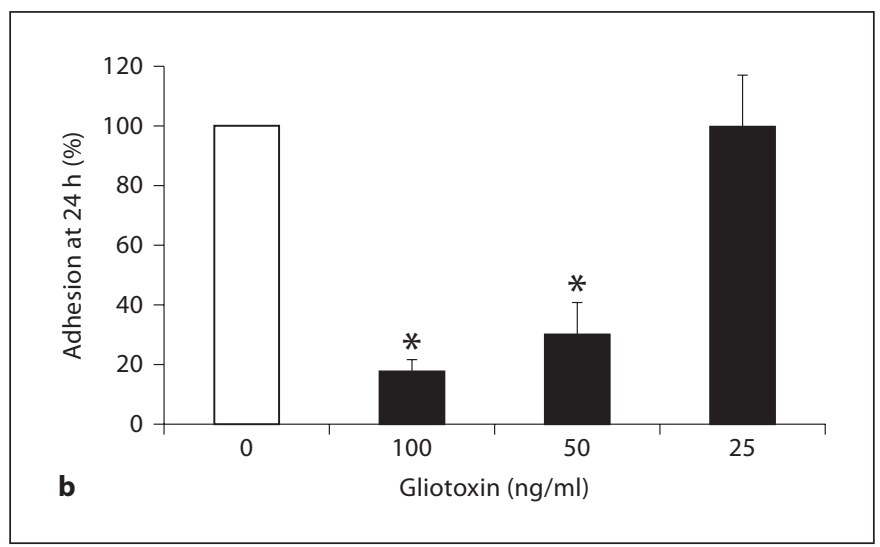

evaluated in the last hour of the experiment. Adhesion in the absence of gliotoxin was considered to be $100 \%$. Means \pm SD of 6 experiments; ${ }^{*} \mathrm{p}<0.0001$, vs. $0 \mathrm{ng} / \mathrm{ml}$ gliotoxin.

monocytic THP-1 cell adhesion to endothelial cells activated with IL-1 $\beta$ for either 4 or $24 \mathrm{~h}$ (fig. 5). Gliotoxin was not cytotoxic for endothelial cells as assessed by the MTT assay. Gliotoxin prevented the nuclear translocation of p65 (RelA) induced by IL-1 $\beta$ (fig. 6a) as well as cell surface expression of the NFKB-dependent adhesion molecules VCAM-1, ICAM-1 and E-selectin (fig. 6b-d).

\section{Gliotoxin Inhibits Neointimal Formation in a Rat \\ Carotid Artery Model of Vascular Injury}

To determine directly whether the in vitro effects of gliotoxin were relevant in vivo, we used the well-established rat carotid injury model to examine its inhibition 

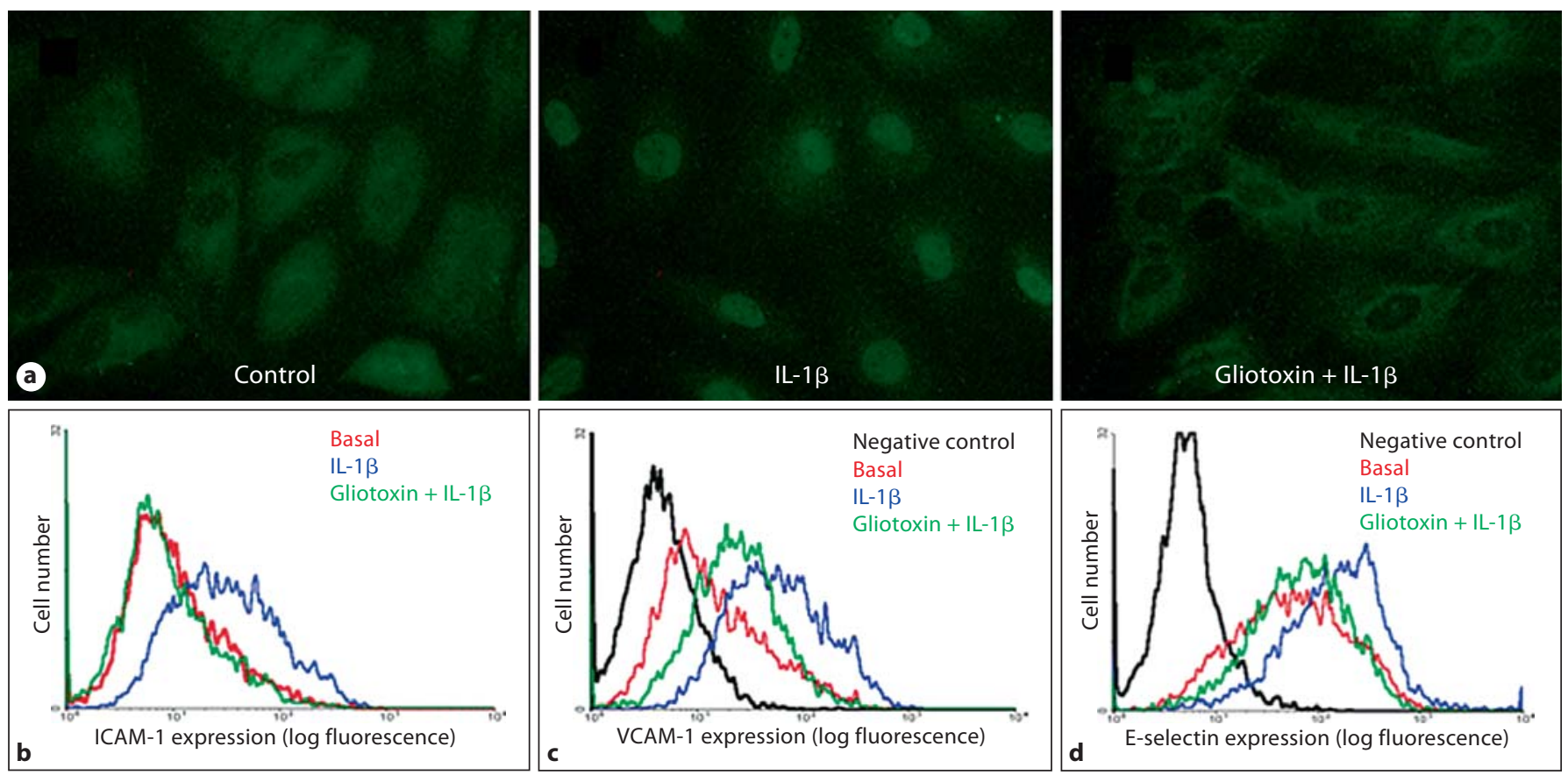

Fig. 6. Gliotoxin prevents NF- $\kappa \mathrm{B}$ activation and reduces adhesion molecule expression induced by IL-1 $\beta$ in endothelial cells. a Preincubation with gliotoxin (100 $\mathrm{ng} / \mathrm{ml}$ for $30 \mathrm{~min}$ ) prevents p65 translocation from the cytosol to the nucleus induced by stimulation with $10 \mathrm{ng} / \mathrm{ml} \mathrm{IL}-1 \beta$ for $60 \mathrm{~min}$. Magnification: $\times 400$. b-d Representative flow-cytometric diagrams showing that pre- treatment with gliotoxin decreases cell surface expression of ICAM-1 (b), VCAM-1 (c) and E-selectin (d) induced by stimulation with $50 \mathrm{ng} / \mathrm{ml} \mathrm{IL-1 \beta}$ for 4 (d) or $24 \mathrm{~h}$ (b, c). Negative control cells were stained with the secondary antibody. They are not presented for ICAM-1 since it overlaps with basal expression. Representative of 6 independent experiments. potential on neointima formation. Uninjured normal carotid arteries presented the endothelial monolayer (fig. 7a). Neointimal hyperplasia dramatically developed within 10 days after angioplasty injury (fig. 7b). Gliotoxin inhibited neointimal thickening (fig. 7c). Digital planimetry revealed a dose-dependent reduction of 42 and $90 \%$ in the intima/media ratio, respectively, for each gliotoxin dose (fig. 8a). The decreased intima/media ratio was associated with a reduction of 51 and $88 \%$ in the degree of stenosis (fig. 8b). The observed changes depended on the reduction in neointima thickness (fig. 8c), without changes in media thickness (fig. 8d).

\section{Gliotoxin Inhibits the Expression of PCNA in Injured} Carotid Artery

PCNA expression was used to assess the effect of gliotoxin on vessel wall cell proliferation. No PCNA-positive cells were observed in the media of normal uninjured and untreated carotid arteries (fig. 9a). PCNA was highly expressed in the neointima and media of arteries from untreated rats 10 days after injury (fig. 9b). Gliotoxin dose- dependently reduced the number of PCNA-positive cells in the neointima (by 31 and $72 \%$ for each dose, respectively) and media (by 55 and 77\% for each dose, respectively; fig. 9c-e).

\section{Discussion}

Cellular responses to vascular injury, e.g. activation, adhesion, migration and proliferation, are involved in vascular proliferative disorders, e.g. atherosclerosis and intimal hyperplasia after angioplasty, reducing the vessel lumen and leading to restenosis [22-25]. Restenosis following percutaneous transluminal angioplasty has emerged as a complex multifactorial pathophysiological problem that has to be addressed by a combined mechanical and pharmacological approach [3, 25-27]. Animal models showing decreased neointimal thickening $[4,5]$ provided the basis for controlled clinical trials with sirolimus- or paclitaxel-eluting stents $[6,7,41-43]$. However, the reduction in restenosis events achieved by such stents 


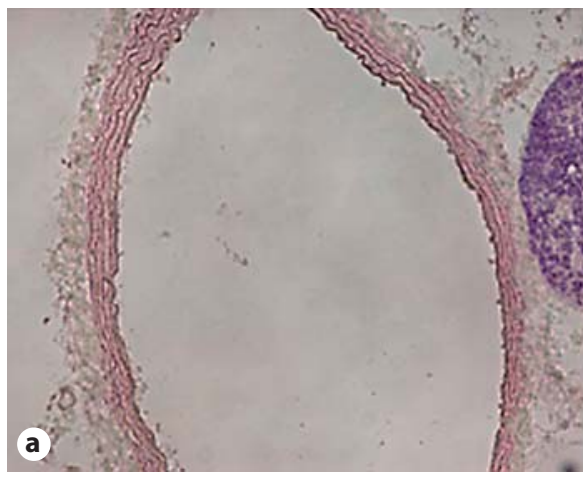

Uninjured

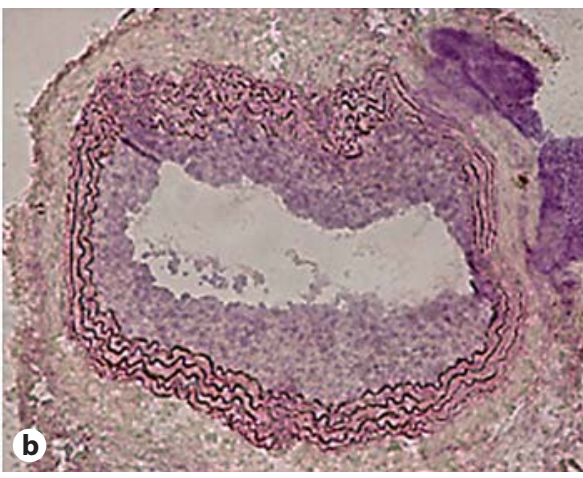

Injured untreated

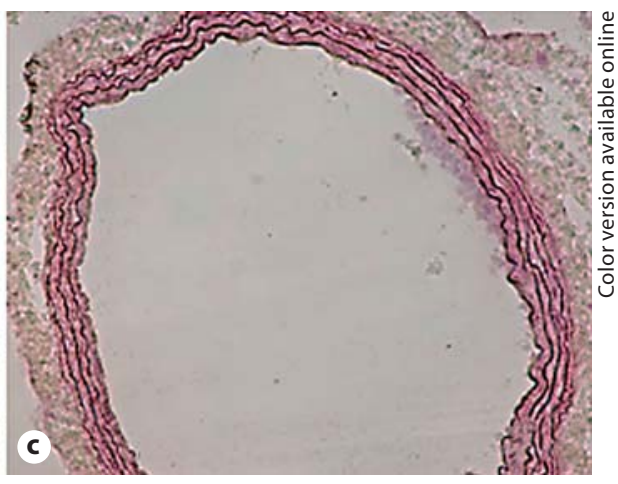

Injured + gliotoxin
Fig. 7. Gliotoxin inhibits neointimal hyperplasia after rat carotid balloon injury. The left common carotid artery was denuded of the endothelium by balloon angioplasty and rats were treated with gliotoxin daily for 10 days. Representative histological cross- sections of uninjured normal (a), injured untreated (b) or injured carotid artery from a rat treated with $400 \mu \mathrm{g}$ gliotoxin/ $\mathrm{kg}$ body weight/day (c). HE. Original magnification, $\times 100$.

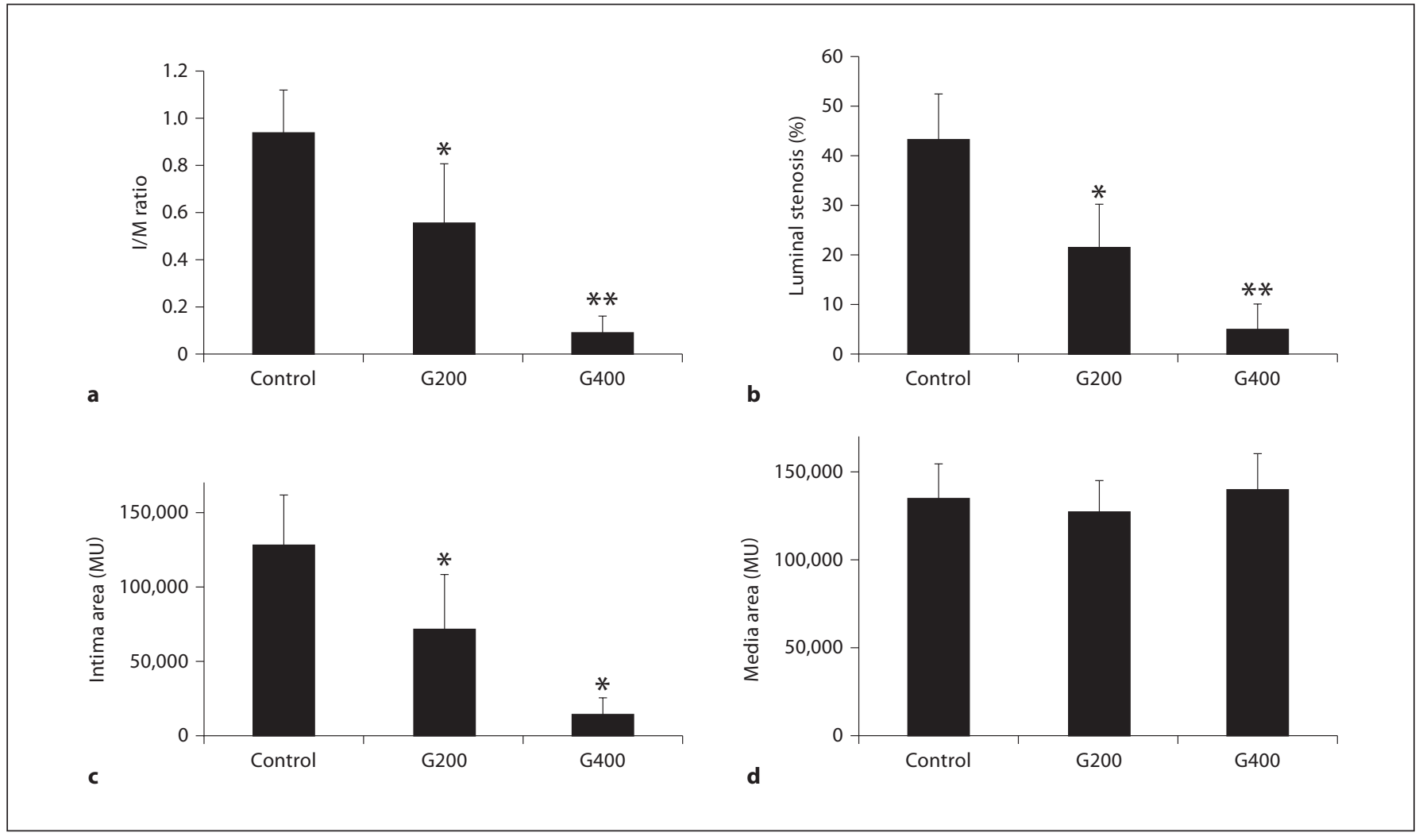

Fig. 8. Gliotoxin significantly reduces the intima/media (I/M) index and the degree of stenosis. Carotid arteries were studied by computer image analysis 10 days after injury. a Ratio of I/M crosssectional areas. b Percentage of luminal stenosis of untreated injured (control) rats, and rats treated with 200 (G200) or $400 \mu \mathrm{g}$ gliotoxin/kg body weight/day (G400). ${ }^{*} \mathrm{p}<0.005 ;{ }^{* *} \mathrm{p}<0.0001$, vs. the control group. The decreased I/M index was due to decreased neointimal formation (c), without changes in media thickness (d). ${ }^{*} \mathrm{p}<0.0001$ vs. control. Morphometry was performed from at least five individual sections of arterial segments of each rat. Values are means \pm SD from 8 animals. $M U=$ Metric units squared. 


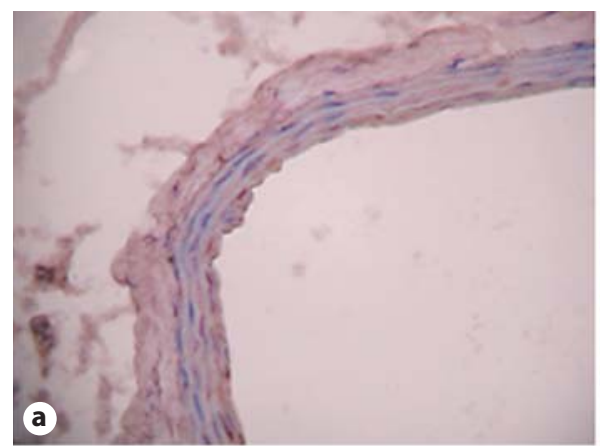

Uninjured

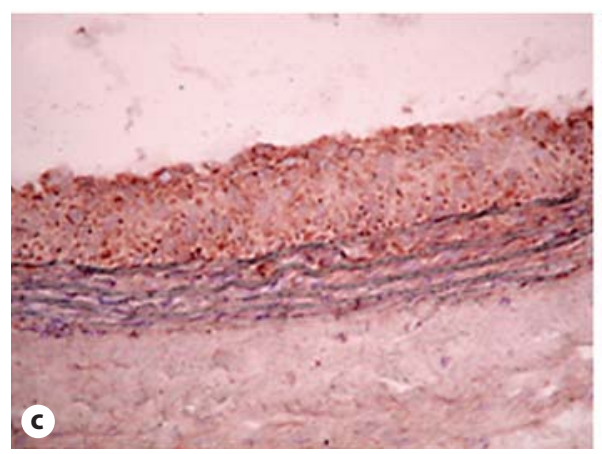

Injured + G200

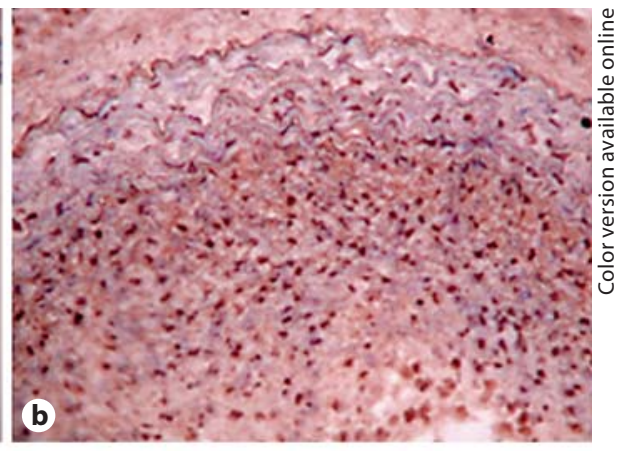

Injured untreated

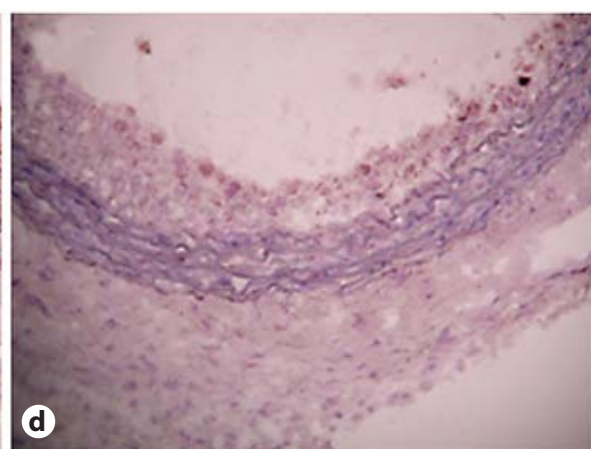

Injured + G400 G400) $\mu \mathrm{g}$ gliotoxin $/ \mathrm{kg}$ body weight/day (d). Representative photomicrographs of carotid sections stained with anti-PCNA antibody. Original magnification, $\times 200$. e PCNA-positive cells in neointima and media of injured arteries are expressed as the percentage of total cells. Data are means \pm SD of 8 rats. The value for each rat is the result of studying 8-10 high-power fields in four sections of each artery (three fields in the $400 \mu \mathrm{g} / \mathrm{kg}$ group because of the small amount of thickened intima). ${ }^{*} \mathrm{p}<0.04,{ }^{* *} \mathrm{p}<0.0005,{ }^{* * *} \mathrm{p}<$ $0.001,{ }^{* * *} \mathrm{p}<0.0003$, vs. injured untreated (control) carotid.

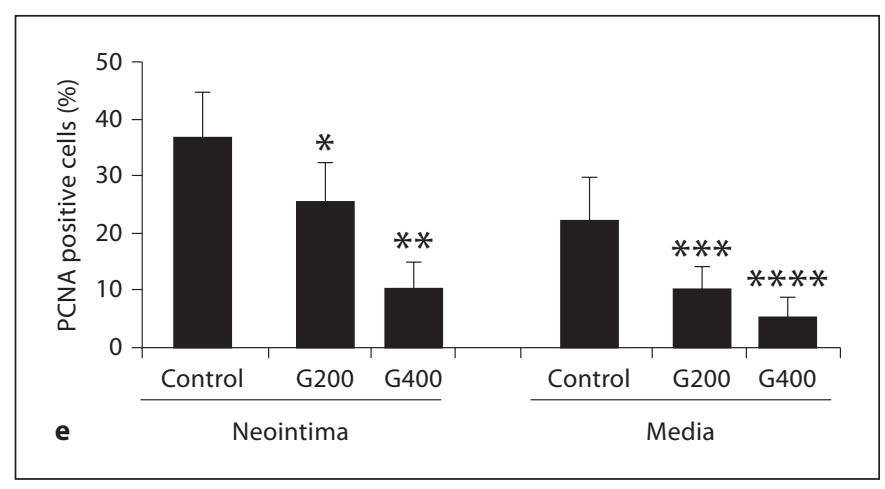

is associated with a higher incidence of late stent thrombosis [8-13]. In this regard, alternative agents providing decreased neointimal thickening should be sought for.

Gliotoxin shows several benefits, including anti-inflammatory and -proliferative activity that may be useful in preventing neointimal formation [15, 17, 21, 44-46]. We explored the actions of gliotoxin on VSMC processes known to contribute to neointima formation. PDGF is a specific mediator of migration of cultured VSMC [30, 31, 47]. Gliotoxin exhibits a powerful antimigratory effect on VSMC, which may be related to its ability to disrupt cytoskeletal proteins. The cytoskeleton mediates essential biological functions, providing a structural framework and dynamic properties, and it is involved in several pathophysiological processes, including atherosclerosis $[48,49]$. Changes in the F-actin cytoskeleton are essential for cell chemotaxis and NF-kB activation [34, 35, 50]. Gliotoxin disorganized F-actin stress fibers and rearranged the distribution of vimentin, a main component of intermediate filaments. The tail domain of vimentin interacts with actin-containing structures, suggesting a cross talk between both cytoskeletal networks [51]. The effect seems to be specific, because gliotoxin did not modify the distribution pattern of $\beta$-tubulin. This observation is consistent with cytoskeletal modulation by gliotoxin in neutrophils [35]. 
The NF- $\mathrm{B} /$ Rel family of transcription factors plays an important role in the inducible regulation of a variety of genes involved in inflammatory, proliferative and migratory responses $[48,52]$. NF- $\kappa \mathrm{B}$ is commonly expressed in the cytoplasm as an inactive dimer complex, generally formed by the p50 and p65 (RelA) subunits, associated to inhibitory I $\mathrm{B}$ p proteins. The activation of NF- $\kappa \mathrm{B}$ requires degradation of $I \kappa B$ and nuclear translocation of the cytoplasmic subunits $[38,40,53]$. NF- $\kappa \mathrm{B}$ is activated in proliferating cultured VSMC [39]. Gliotoxin is a powerful and specific inhibitor of the activation of NF- $\kappa \mathrm{B}$ in various cell types [17, 19,20], but it had not been studied in vascular cells. We here show that gliotoxin blocks the nuclear translocation of the p65 subunit in rat VSMC as well as in endothelial cells, indicating inhibition of NF- $\kappa \mathrm{B}$ activation. NF- $\kappa \mathrm{B}$ is greatly induced in the rat carotid injury model [39], and p65 antisense oligonucleotides reduce neointimal formation [54]. NF- $\kappa \mathrm{B}$ activation has also been found within human atherosclerotic lesions or after angioplasty, but not in normal arteries $[38,55,56]$.

The observation that gliotoxin inhibits migration, proliferation and nuclear translocation of the NF- $\kappa$ B p 65 subunit in cultured VSMC might be relevant to the beneficial effect observed in the model of carotid artery damage by angioplasty. Gliotoxin markedly suppresses neointimal development, reducing up to $90 \%$ of both the intima/media ratio and the degree of luminal stenosis. Indeed, a potent in vivo antiproliferative action of gliotoxin was documented in the neointima and media of injured vessels. These data provide evidence that gliotoxin confers protection against aberrant VSMC proliferation under pathological states. Gliotoxin decreased VSMC PCNA expression in culture and in vivo. PCNA is both a marker of cell division and a therapeutic target $[36,37]$ as it is highly expressed in rat carotid artery after balloon injury, and PCNA antisense oligonucleotides limit intimal hyperplasia [18, 57].

Inflammation has been associated with impaired endothelialization or higher restenosis rates after the use or paclitaxel or ${ }^{32} \mathrm{P}$-containing stents $[58,59]$. Gliotoxin also has direct actions on the endothelium, reducing the expression of NF- $\kappa \mathrm{B}$-dependent adhesion molecules and leukocyte adhesion in activated cultured endothelial cells. Adhesion molecules are required for adhesion and recruitment of leukocytes at the sites of injury. Indeed, reduced leukocyte infiltration had previously been described in gliotoxin-treated animals with colitis or glomerulonephritis [21, 60]. Indeed, gliotoxin has been shown to decrease inflammation in experimental colitis $[61,62]$, cornea [63] skin [15] and kidney [21]. In this re- gard, there was no clear evidence of toxicity in our model or other models [21]. However, gliotoxin is a mycotic toxin and its long-term systemic use in humans might be associated with toxic effects. Its potential toxicity would be decreased by its local release from a drug-eluting stent. The concentrations found to have beneficial effects on VSMC and endothelium $(100 \mathrm{ng} / \mathrm{ml})$ are well below those toxic for cells in culture [64] and are within the range found in the serum of patients with invasive aspergillosis [65].

In summary, gliotoxin prevented neointimal formation following balloon injury to carotid arteries. This beneficial effect may be related to direct effects on VSMC, since gliotoxin inhibited VSMC migration, proliferation and NF-kB activation, as well as on the endothelium, where it decreased leukocyte adhesion. Thus, we have identified new cell targets for gliotoxin actions and a new compound which may be useful to prevent restenosis.

\section{Acknowledgments}

This study was supported by grants from the Ministerio de Educación y Cultura (PM97-0089), the Ministerio de Ciencia y Tecnología (BFI2002-03892; to J.G.-C.) and the Ministerio de Sanidad y Consumo (FIS; PI06/0046 and RETIC REDINREN 06/0016, CAM: S-BIO-0283-2006 Fracaso renal-CM to A.O.). M.P. and M.C.I. were supported by the Fundación Conchita Rábago de Jiménez Díaz and A.O. by the Programa de Intensificación de la actividad investigadora (Comunidad de Madrid-Agencia Lain Entralgo/ISCIII.

References sis. Prog Cardiovasc Dis 1997;40:107-116.

12 Faxon DP: Systemic drug therapy for restenosis: 'deja vu all over again'. Circulation 2002;106:2296-2298.

3 Libby P, Tanaka H: The molecular bases of restenosis. Prog Cardiovasc Dis 1997;40:97106.

4 Gallo R, Padurean A, Jayaraman T, Marx S, Roque M, Adelman S, Chesebro J, Fallon J, Fuster V, Marks A, Badimon JJ: Inhibition of intimal thickening after balloon angioplasty in porcine coronary arteries by targeting regulators of the cell cycle. Circulation 1999; 99:2164-2170.

-5 Sollott SJ, Cheng L, Pauly RR, Jenkins GM, Monticone RE, Kuzuya M, Froehlich JP, Crow MT, Lakatta EG, Rowinsky EK: Taxol inhibits neointimal smooth muscle cell accumulation after angioplasty in the rat. J Clin Invest 1995;95:1869-1876. 
6 Sousa JE, Costa MA, Abizaid A, Sousa AG, Feres F, Mattos LA, Centemero M, Maldonado G, Abizaid AS, Pinto I, Falotico R, Jaeger J, Popma JJ, Serruys PW: Sirolimus-eluting stent for the treatment of in-stent restenosis: a quantitative coronary angiography and three-dimensional intravascular ultrasound study. Circulation 2003;107:24-27.

-7 Tanabe K, Serruys PW, Grube E, Smits PC, Selbach G, van der Giessen WJ, Staberock M, de FP, Muller R, Regar E, Degertekin M, Ligthart JM, Disco C, Backx B, Russell ME: TAXUS III Trial: in-stent restenosis treated with stent-based delivery of paclitaxel incorporated in a slow-release polymer formulation. Circulation 2003;107:559-564.

$\checkmark 8$ Curfman GD, Morrissey S, Jarcho JA, Drazen JM: Drug-eluting coronary stents promise and uncertainty. N Engl J Med 2007; 356:1059-1060.

$>9$ Spaulding C, Daemen J, Boersma E, Cutlip DE, Serruys PW: A pooled analysis of data comparing sirolimus-eluting stents with bare-metal stents. N Engl J Med 2007;356: 989-997.

10 Stone GW, Moses JW, Ellis SG, Schofer J, Dawkins KD, Morice MC, Colombo A, Schampaert E, Grube E, Kirtane AJ, Cutlip DE, Fahy M, Pocock SJ, Mehran R, Leon MB: Safety and efficacy of sirolimus- and paclitaxel-eluting coronary stents. N Engl J Med 2007;356:998-1008.

11 Lagerqvist B, James SK, Stenestrand U, Lindback J, Nilsson T, Wallentin L: Long-term outcomes with drug-eluting stents versus bare-metal stents in Sweden. N Engl J Med 2007;356:1009-1019.

-12 Mauri L, Hsieh WH, Massaro JM, Ho KK, D’Agostino R, Cutlip DE: Stent thrombosis in randomized clinical trials of drug-eluting stents. N Engl J Med 2007;356:1020-1029.

$\checkmark 13$ Kastrati A, Mehilli J, Pache J, Kaiser C, Valgimigli M, Kelbaek H, Menichelli M, Sabate M, Suttorp MJ, Baumgart D, Seyfarth M, Pfisterer ME, Schomig A: Analysis of 14 trials comparing sirolimus-eluting stents with bare-metal stents. N Engl J Med 2007;356: 1030-1039.

14 Gardiner DM, Waring P, Howlett BJ: The epipolythiodioxopiperazine (ETP) class of fungal toxins: distribution, mode of action, functions and biosynthesis. Microbiology 2005;151:1021-1032.

-15 Mullbacher A, Moreland AF, Waring P, Sjaarda A, Eichner RD: Prevention of graftversus-host disease by treatment of bone marrow with gliotoxin in fully allogeneic chimeras and their cytotoxic T cell repertoire. Transplantation 1988;46:120-125.

-16 Mullbacher A, Waring P, Eichner RD: Identification of an agent in cultures of Aspergillus fumigatus displaying anti-phagocytic and immunomodulating activity in vitro. J Gen Microbiol 1985;131:1251-1258.
17 Pahl HL, Krauss B, Schulze-Osthoff K, Decker T, Traenckner EB, Vogt M, Myers C, Parks T, Warring P, Muhlbacher A, Czernilofsky AP, Baeuerle PA: The immunosuppressive fungal metabolite gliotoxin specifically inhibits transcription factor NF- $\kappa$ B. J Exp Med 1996;183:1829-1840.

18 Speir E, Epstein SE: Inhibition of smooth muscle cell proliferation by an antisense oligodeoxynucleotide targeting the messenger RNA encoding proliferating cell nuclear antigen. Circulation 1992;86:538-547.

19 Elsharkawy AM, Wright MC, Hay RT, Arthur MJ, Hughes T, Bahr MJ, Degitz K, Mann DA: Persistent activation of nuclear factor$\kappa \mathrm{B}$ in cultured rat hepatic stellate cells involves the induction of potentially novel Rellike factors and prolonged changes in the expression of IкB family proteins. Hepatology 1999;30:761-769.

20 Ward C, Chilvers ER, Lawson MF, Pryde JG, Fujihara S, Farrow SN, Haslett C, Rossi AG: $\mathrm{NF}-\kappa \mathrm{B}$ activation is a critical regulator of human granulocyte apoptosis in vitro. J Biol Chem 1999;274:4309-4318.

-21 Lopez-Franco O, Suzuki Y, Sanjuan G, Blanco J, Hernandez-Vargas P, Yo Y, Kopp J, Egido J, Gomez-Guerrero C: Nuclear factorkappa B inhibitors as potential novel antiinflammatory agents for the treatment of immune glomerulonephritis. Am J Pathol 2002;161:1497-1505.

22 Libby P, Ridker PM, Maseri A: Inflammation and atherosclerosis. Circulation 2002;105: 1135-1143.

23 Paoletti R, Gotto AM Jr, Hajjar DP: Inflammation in atherosclerosis and implications for therapy. Circulation 2004;109:III20III26.

24 Ross R: Atherosclerosis is an inflammatory disease. Am Heart J 1999;138:S419-S420.

25 Casscells W: Migration of smooth muscle and endothelial cells. Critical events in restenosis. Circulation 1992;86:723-729.

26 Reidy MA: Factors controlling smooth-muscle cell proliferation. Arch Pathol Lab Med 1992;116:1276-1280.

-27 Schwartz SM: Perspectives series: cell adhesion in vascular biology. Smooth muscle migration in atherosclerosis and restenosis. J Clin Invest 1997;99:2814-2816.

-28 Pozo M, Castilla V, Gutierrez C, de Nicolás R, Egido J, Gonzalez-Cabrero J: Ursolic acid inhibits neointima formation in the rat carotid artery injury model. Atherosclerosis 2006;184:53-62.

29 Jaffe EA, Nachman RL, Becker CG, Minick CR: Culture of human endothelial cells derived from umbilical veins. Identification by morphologic and immunologic criteria. J Clin Invest 1973;52:2745-2756.
30 Bilato C, Pauly RR, Melillo G, Monticone R, Gorelick-Feldman D, Gluzband YA, Sollott SJ, Ziman B, Lakatta EG, Crow MT: Intracellular signaling pathways required for rat vascular smooth muscle cell migration. Interactions between basic fibroblast growth factor and platelet-derived growth factor. J Clin Invest 1995;96:1905-1915.

31 Jawien A, Bowen-Pope DF, Lindner V, Schwartz SM, Clowes AW: Platelet-derived growth factor promotes smooth muscle migration and intimal thickening in a rat model of balloon angioplasty. J Clin Invest 1992; 89:507-511.

32 Poon M, Marx SO, Gallo R, Badimon JJ, Taubman MB, Marks AR: Rapamycin inhibits vascular smooth muscle cell migration. J Clin Invest 1996;98:2277-2283.

-33 Carmichael J, DeGraff WG, Gazdar AF, Minna JD, Mitchell JB: Evaluation of a tetrazolium-based semiautomated colorimetric assay: assessment of radiosensitivity. Cancer Res 1987;47:943-946.

>34 Ren XD, Kiosses WB, Schwartz MA: Regulation of the small GTP-binding protein Rho by cell adhesion and the cytoskeleton. EMBO J 1999;18:578-585.

-35 van Nieuw Amerongen GP, van Hinsbergh VW: Cytoskeletal effects of rho-like small guanine nucleotide-binding proteins in the vascular system. Arterioscler Thromb Vasc Biol 2001;21:300-311.

36 Jaskulski D, Gatti C, Travali S, Calabretta B, Baserga R: Regulation of the proliferating cell nuclear antigen cyclin and thymidine kinase mRNA levels by growth factors. J Biol Chem 1988;263:10175-10179.

37 Wei GL, Krasinski K, Kearney M, Isner JM, Walsh K, Andres V: Temporally and spatially coordinated expression of cell cycle regulatory factors after angioplasty. Circ Res 1997;80:418-426.

38 Bourcier T, Sukhova G, Libby P: The nuclear factor kappa-B signaling pathway participates in dysregulation of vascular smooth muscle cells in vitro and in human atherosclerosis. J Biol Chem 1997;272:1581715824.

39 Landry DB, Couper LL, Bryant SR, Lindner $\mathrm{V}$ : Activation of the NF-kappa B and I kappa B system in smooth muscle cells after rat arterial injury. Induction of vascular cell adhesion molecule-1 and monocyte chemoattractant protein-1. Am J Pathol 1997;151: 1085-1095.

40 Obata H, Biro S, Arima N, Kaieda H, Kihara T, Eto H, Miyata M, Tanaka H: NF-kappa B is induced in the nuclei of cultured rat aortic smooth muscle cells by stimulation of various growth factors. Biochem Biophys Res Commun 1996;224:27-32.

-41 Degertekin M, Saia F, Lemos PA, Arampatzis CA, Serruys PW: Sirolimus-eluting stents for the treatment of in-stent restenosis. Minerva Cardioangiol 2003;51:475-484. 
-42 Sousa JE, Costa MA, Sousa AG, Abizaid AC, Seixas AC, Abizaid AS, Feres F, Mattos LA, Falotico R, Jaeger J, Popma JJ, Serruys PW: Two-year angiographic and intravascular ultrasound follow-up after implantation of sirolimus-eluting stents in human coronary arteries. Circulation 2003;107:381-383.

-43 Park SJ, Shim WH, Ho DS, Raizner AE, Park SW, Hong MK, Lee CW, Choi D, Jang Y, Lam R, Weissman NJ, Mintz GS: A paclitaxeleluting stent for the prevention of coronary restenosis. N Engl J Med 2003;348:15371545.

44 Mullbacher A, Waring P, Tiwari-Palni U, Eichner RD: Structural relationship of epipolythiodioxopiperazines and their immunomodulating activity. Mol Immunol 1986; 23:231-235.

-45 Sutton P, Newcombe NR, Waring P, Mullbacher A: In vivo immunosuppressive activity of gliotoxin, a metabolite produced by human pathogenic fungi. Infect Immun 1994; 62:1192-1198.

-46 Waring P, Beaver J: Gliotoxin and related epipolythiodioxopiperazines. Gen Pharmacol 1996;27:1311-1316.

-47 Poon M, Hsu WC, Bogdanov VY, Taubman MB: Secretion of monocyte chemotactic activity by cultured rat aortic smooth muscle cells in response to PDGF is due predominantly to the induction of JE/MCP-1. Am J Pathol 1996;149:307-317.

48 Lee JS, Gotlieb AI: Microtubule-actin interactions may regulate endothelial integrity and repair. Cardiovasc Pathol 2002;11:135140.

49 Shimokawa H: Rho-kinase as a novel therapeutic target in treatment of cardiovascular diseases. J Cardiovasc Pharmacol 2002;39: 319-327.

-50 Taubman MB, Rollins BJ, Poon M, Marmur J, Green RS, Berk BC, Nadal-Ginard B: JE mRNA accumulates rapidly in aortic injury and in platelet-derived growth factor-stimulated vascular smooth muscle cells. Circ Res 1992;70:314-325.
1 Cary RB, Klymkowsky MW, Evans RM, Domingo A, Dent JA, Backhus LE: Vimentin's tail interacts with actin-containing structures in vivo. J Cell Sci 1994;107(pt 6):16091622.

52 Zhu P, Xiong W, Rodgers G, Qwarnstrom EE: Regulation of interleukin 1 signalling through integrin binding and actin reorganization: disparate effects on NF- $\kappa \mathrm{B}$ and stress kinase pathways. Biochem J 1998. 330(Pt 2):975-981.

53 Yamamoto Y, Gaynor RB: Therapeutic potential of inhibition of the NF- $\kappa \mathrm{B}$ pathway in the treatment of inflammation and cancer. J Clin Invest 2001;107:135-142.

54 Autieri MV, Yue TL, Ferstein GZ, Ohlstein E: Antisense oligonucleotides to the p65 subunit of NF-kB inhibit human vascular smooth muscle cell adherence and proliferation and prevent neointima formation in rat carotid arteries. Biochem Biophys Res Commun 1995;213:827-836.

55 Brand K, Page S, Rogler G, Bartsch A, Brandl R, Knuechel R, Page M, Kaltschmidt C, Baeuerle PA, Neumeier D: Activated transcription factor nuclear factor-kappa B is present in the atherosclerotic lesion. J Clin Invest 1996;97:1715-1722.

56 Ritchie ME: Nuclear factor- $\kappa \mathrm{B}$ is selectively and markedly activated in humans with unstable angina pectoris. Circulation 1998;98: 1707-1713.

57 Simons M, Edelman ER, Rosenberg RD: Antisense proliferating cell nuclear antigen oligonucleotides inhibit intimal hyperplasia in a rat carotid artery injury model. J Clin Invest 1994;93:2351-2356.

58 Lim SY, Jeong MH, Hong SJ, Lim DS, Moon JY, Hong YJ, Kim JH, Ahn Y, Kang JC: Inflammation and delayed endothelization with overlapping drug-eluting stents in a porcine model of in-stent restenosis. Circ J 2008;72:463-468.
59 Wexberg P, Jordanova N, Strehblow C, Syeda B, Meyer B, Charvat S, Zorn G, Scheinig D, Wojta J, Huber K, Glogar D, Gyongyosi M: Time course of prothrombotic and proinflammatory substance release after intracoronary stent implantation. Thromb Haemost 2008;99:739-748

60 Farkas S, Herfarth H, Rossle M, Schroeder J, Steinbauer M, Guba M, Beham A, Scholmerich J, Jauch KW, Anthuber M: Quantification of mucosal leucocyte endothelial cell interaction by in vivo fluorescence microscopy in experimental colitis in mice. Clin Exp Immunol 2001;126:250-258.

-61 Fitzpatrick LR, Wang J, Le T: Gliotoxin, an inhibitor of nuclear factor-kappa B, attenuates peptidoglycan-polysaccharide-induced colitis in rats. Inflamm Bowel Dis 2002;8: 159-167.

62 Herfarth H, Brand K, Rath HC, Rogler G, Scholmerich J, Falk W: Nuclear factor-kappa $B$ activity and intestinal inflammation in dextran sulphate sodium (DSS)-induced colitis in mice is suppressed by gliotoxin. Clin Exp Immunol 2000;120:59-65.

-63 Sonoda K, Sakamoto T, Yoshikawa H, Ashizuka S, Ohshima Y, Kishihara K, Nomoto K, Ishibashi $\mathrm{T}$, Inomata $\mathrm{H}$ : Inhibition of corneal inflammation by the topical use of Ras farnesyltransferase inhibitors: selective inhibition of macrophage localization. Invest Ophthalmol Vis Sci 1998;39:2245-2251.

64 Comera C, Andre K, Laffitte J, Collet X, Galtier P, Maridonneau-Parini I: Gliotoxin from Aspergillus fumigatus affects phagocytosis and the organization of the actin cytoskeleton by distinct signalling pathways in human neutrophils. Microbes Infect 2007;9: 47-54.

65 Lewis RE, Wiederhold NP, Chi J, Han XY, Komanduri KV, Kontoyiannis DP, Prince RA: Detection of gliotoxin in experimental and human aspergillosis. Infect Immun 2005;73:635-637. 